\title{
THE EFFECT OF LAND CHARACTERISTICS ON AGRICULTURAL PRODUCTIVITY USING MULTIPLE LINEAR REGRESSION METHOD IN MADIUN REGENCY, EAST JAVA
}

\author{
Elya Pratiwi Istifaroh $^{I}$, Rika Harini ${ }^{1}$ \\ ${ }^{1}$ Department of Environmental Geography, Faculty of Geography, Universitas Gadjah Mada, Indonesia
}

\begin{abstract}
Agriculture is an important sector to support national food availability. Soil and climatic conditions in Indonesia are very suitable for agriculture. However, the land characteristics in each region are different, Especially in Madiun Regency, where this study is conducted. This study aims to determine what commodities are suitable for the characteristics of the land based on land suitability and how land characteristics influence agricultural productivity. The data used in this research is secondary data. Determination of agricultural commodities is carried out by cross-checking between land characteristics and guidelines for agricultural commodity land requirements. There are six types of agricultural commodities that are suitable for land characteristics in Madiun Regency. The effect of land characteristics consisting of several parameters on agricultural productivity was sought using multiple linear regression methods. The processing results are known that 8 variables of land characteristics significantly affect agricultural productivity by $93 \%$. The independent variables were tested using the Simultaneous F-Test and were known to have a simultaneous (together) effect on agricultural productivity. In addition, a Partial T-Test was conducted, and it was found that there were only two variables that had a partial effect, namely the soil CEC characteristics and the sand characteristics.
\end{abstract}

\section{Introduction}

The Indonesian territory, which is located in the equatorial area and has two seasons, greatly supports soil fertility in various parts of Indonesia. Vast land areas are in provision for forests, agricultural land, and agricultural land. Natural resources and abundant soil fertility is an advantage for the people of Indonesia. Indonesia is known as an agricultural country because most of its people work as farmers. The agricultural sector is the mainstay for Indonesia in order to fulfill its national food supply.

Since ancient times, the international community has ogled the agricultural sector in Indonesia, so it needs more advanced development to get maximum results from the agricultural sector. Indonesia's dense population also encourages greater food demand, which requires more agricultural products (productivity). One of the factors that affects agricultural productivity is fertility [1]. Therefore, knowledge about land fertility or land characteristics needs to be deepened to implement strategies in farming.

Characteristics of land in Indonesia's territory are very varied. It can be clearly seen from the types of agricultural commodities in Indonesia which are also diverse. One of the studied areas in this research is Madiun Regency. According to [2], it has a remarkable carrying capacity of agricultural land to provide food self-sufficiency for its residents. In addition, the need for agricultural land in Madiun Regency is very well met by production land, which is still very large with the support of locations in the lowlands. Although the characteristics of the land in Madiun Regency tend to be the same, there are differences because the parameters of the land characteristics are quite large, such as rainfall, humidity, temperature, soil $\mathrm{pH}, \mathrm{CEC}$, nutrients, etc.
Based on land characteristics data, it can be known what agricultural commodities are suitable for the land, so that we can plant agricultural commodities according to the criteria for the land to get maximum productivity. In addition, according to [3],the determination of land suitability needs to be carried out as a guide for agricultural development that is following the principles of land conservation. Land characteristics consisting of several parameters can affect the results of agricultural productivity. However, we do not know how much influence it has and what characteristic parameters affect agricultural productivity. This study aims to determine how land characteristics influence agricultural productivity.

\section{Methodology}

This research has the following research stages:

\subsection{Research Time and Place}

This research was conducted in Madiun Regency using units of analysis per subdistrict. The time used in this study is one year, namely 2018 because this study uses secondary data that considers the completeness of the data. The research location in Madiun Regency can be seen in the map image below: 


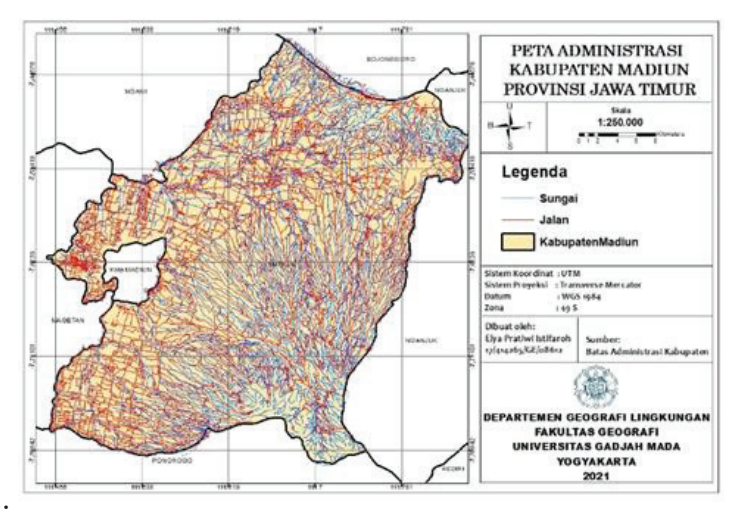

Fig. 1. Madiun Regency research location map.

\subsection{Population and Sample}

The population in this study is all land in Madiun Regency, while the research sample uses data on land characteristics of each sub-district in Madiun Regency, totaling 15 sub-districts.

\subsection{Data}

There are two variables for the data used in this study namely the influencing variable and the affected variable. The influence variable uses land characteristic data, which consists of several parameters, namely as follows:

Table 1. Data Types and Source.

\begin{tabular}{|l|l|}
\hline $\begin{array}{l}\text { Parameters of } \\
\text { Land } \\
\text { Characteristics }\end{array}$ & Source \\
\hline Rainfall & BMKG online \\
\hline Temperature & BMKG online \\
\hline Humidity & BMKG online \\
\hline Soil pH & Study of literature[4] \\
\hline $\begin{array}{l}\text { Soil CEC } \\
\text { c-organic }\end{array}$ & Study of literature [4] \\
\hline $\begin{array}{l}\text { Soil texture } \\
\text { (sand, dust, } \\
\text { clay) }\end{array}$ & Study of literature [4] \\
\hline $\begin{array}{l}\text { Soil nutrient } \\
\text { content (N, P, } \\
\text { K, Na, Ca, Mg) }\end{array}$ & Study of literature [4] \\
\hline
\end{tabular}

In addition to land characteristics data, there is also an affected variable in this study: agricultural productivity. This study uses seven types of commodity limits which are also the leading commodities in Madiun Regency, including types of rice, corn, soybeans, green beans, peanuts, sweet potatoes, and cassava. The agricultural productivity data was obtained through the BPS of Madiun Regency in 2019[5].

\subsection{Processing and data Analysis}

The purpose of this research is to find out what commodities are suitable for land characteristics in Madiun Regency using the cross-check technique concerning land requirements in the "Technical Guidelines for Land Evaluation for Agricultural Commodities" or Technical Guidelines published by the Center for Research and Development of Agricultural Land Resources, Ministry of Agriculture in 2011. Then, from several suitable commodities per sub-district, the most suitable commodities for the parameters of the characteristics of the land can be concluded. The most suitable commodities per sub-district were analyzed by using descriptive qualitative approach.

The effect of land characteristics variables on agricultural productivity variables were tested using SPSS software. The first stage is carried out on the data, namely the normality test of the data using the Shapiro Wilk method. This method is in accordance with this study with data of less than 50 samples [6]. The data is considered normally distributed if the significance value is $>0.05$, and vice versa. Then the land characteristics data, which consists of several parameters and agricultural productivity data which are normally distributed, are carried out with multiple linear regression to determine the effect. This numerous linear regression method aims to determine the effect of two or more independent variables on the dependent variable [7]. The magnitude of the effect can be seen through the value of R2, where if R2 is close to 1, then the influence of the independent variable is considered perfect. On the contrary, the closer the value of R2 is to 0 , the weaker the effect will be. In addition, the effect of independent variables can also be known through the significance level in the Model Summary table, where if the value of Sig. F. Change $<0.05$, then there is a significant effect, and otherwise.

After knowing the effect of independent variables in general, it can be continued with hypothesis testing, namely the Simultaneous F Test and Partial T-Test. A simultaneous F-test is used to determine the effect of independent variables simultaneously (together). In contrast,a Partial T-test is used to test the impact of independent variables (alone) partially. The two tests have the same method, namely by comparing $\mathrm{F}$ count and $\mathrm{F}$ table or $\mathrm{T}$ count and $\mathrm{T}$ table values.

\section{Result and Discussion}

\subsection{Commodities that match the characteristics of the land in Madiun Regency}

Commodities that match the characteristics of the land in the Madiun Regency per sub-district analysis unit produce several commodities in accordance with each sub-district's land characteristics. The results of this study can be seen in the table below: 
Table 2. Suitability of Agricultural Land.

\begin{tabular}{|c|c|c|c|c|c|c|}
\hline \multirow[b]{2}{*}{ Districts } & \multicolumn{6}{|c|}{ Commodity Directive } \\
\hline & Cassava & Rice & $\begin{array}{l}\text { Sweet } \\
\text { potato }\end{array}$ & Soy & $\begin{array}{l}\text { Green } \\
\text { beans }\end{array}$ & Corns \\
\hline Balerejo & & $\sqrt{ }$ & & & & \\
\hline Dagangan & $\sqrt{ }$ & & & & & \\
\hline Dolopo & $\sqrt{ }$ & & $\sqrt{ }$ & & & \\
\hline Geger & $\sqrt{ }$ & & $\sqrt{ }$ & & & \\
\hline Gemarang & $\sqrt{ }$ & & $\sqrt{ }$ & & & \\
\hline Jiwan & & $\sqrt{ }$ & & & & \\
\hline Kare & $\sqrt{ }$ & & & & & \\
\hline Kebonsari & $\sqrt{ }$ & & $\sqrt{ }$ & & & \\
\hline Madiun & & $\sqrt{ }$ & & & & \\
\hline Mejayan & & $\sqrt{ }$ & & & & \\
\hline $\begin{array}{l}\text { Pilang } \\
\text { kenceng }\end{array}$ & & $\sqrt{ }$ & & $\sqrt{ }$ & $\sqrt{ }$ & \\
\hline Saradan & & & & & & $\sqrt{ }$ \\
\hline Sawahan & & & & $\sqrt{ }$ & & \\
\hline Wonosari & $\sqrt{ }$ & $\sqrt{ }$ & $\sqrt{ }$ & & & \\
\hline Wungu & $\sqrt{ }$ & $\sqrt{ }$ & $\sqrt{ }$ & & & \\
\hline
\end{tabular}

Based on the results of a cross-check between several parameters of land characteristics concerning land requirements, it produces commodity directions in accordance with the characteristics of the land in Madiun Regency as shown in the table above. Some sub-districts are suitable for one type of commodity, and some other sub-districts are suitable for three commodities at once. 8 sub-districts are suitable for only one type of commodity, while those that are suitable for two commodities are 4 sub-districts, and those that are suitable for three commodities are 3 sub-districts.

The table above shows six suitable commodities in the Madiun Regency, where previously seven commodities were selected to suit the characteristics of the land. One commodity that is not in accordance with the characteristics of the land in all sub-districts in the Madiun Regency is peanuts because this commodity has several land requirements that are not in accordance with the characteristics of the land.

The most suitable commodity for the most part in the Madiun Regency area is cassava which is suitable for 8 sub-districts out of 15 sub-districts. Furthermore, rice commodities are suitable for 7 sub-districts, sweet potato commodities are suitable for 6 sub-districts, soybean commodities are suitable for 2 sub-districts, and green beans and corn are suitable for 1 sub-district. The sub-districts that are suitable for three types of commodities are Pilangkenceng, Wonosari, and Wungu sub-districts.

Directions for the use of agricultural land for various types of agricultural commodities can be used as a reference for farmers to choose what commodities are in accordance with the characteristics of the land. However, farmers still have to apply cultivation patterns as in the study [8] regarding farmers in Saradan District who always replace commodities according to cultivation pattern to replace missing nutrients.

\subsection{The Relationship between the Suitability of Agricultural Land and Agricultural Productivity}

The type of commodity that is suggested for agricultural land use can be considered as a strategy to maximize the result of its produce. However, nowadays many farmers choose types of agricultural commodities without knowing in detail how the characteristics of the area are, so that sometimes there are differences between the results of the land suitability analysis and the reality on the ground. Below is the comparison between land suitability and agricultural productivity yields of various commodities.

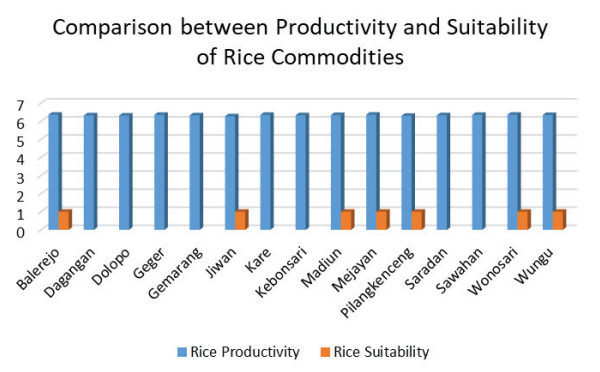

Fig. 2. Comparison between Productivity and Suitability of Rice Commodities.

The diagram above shows the comparison between the productivity and the corresponding sub-districts of rice commodities. The blue bars represent the rice productivity in each district, while the orange bars represent the suitability of the land areas for rice produce in each district. It can be seen in the graph that rice productivity tends to be equal and evenly distributed in all districts. However, according to the results of land suitability, only a few sub-districts are suitable for rice commodities. In addition, some sub-districts which serve for the use of rice land but have low rice productivity among other sub-districts, namely Jiwan District and Pilangkenceng District. This can be due to many factors, such as the lack of farmers' strategies in rice cultivation.

Comparison between Productivity and Suitability of Cassava Commodities

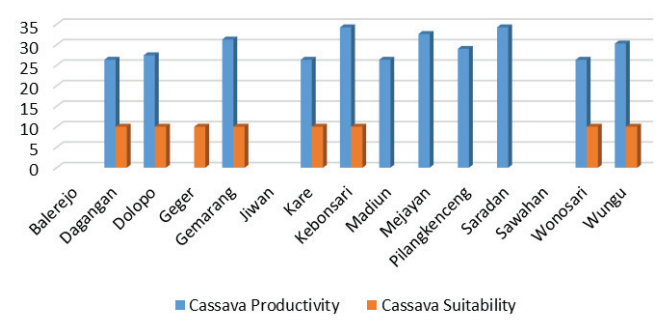

Fig. 3. Comparison between Productivity and Suitability of Cassava Commodities.

Another commodity that is the direction of land use in Madiun Regency is cassava. These commodities are often found in the Madiun Regency area as staple crops of the ancients. Cassava productivity in 2017 based on 
data from BPS was produced by several sub-districts except Geger, Jiwan, and Sawahan sub-districts. However, based on the direction of land use in Geger District, it is in fact suitable for cassava commodities. This is not in accordance with actual circumstances where there is no cassava productivity at all. This can happen due to several factors, such as farmers' desire to choose cassava to be planted on their agricultural land because the selling price is low.

Comparison between Productivity and Suitability of Sweet Potato Commodities

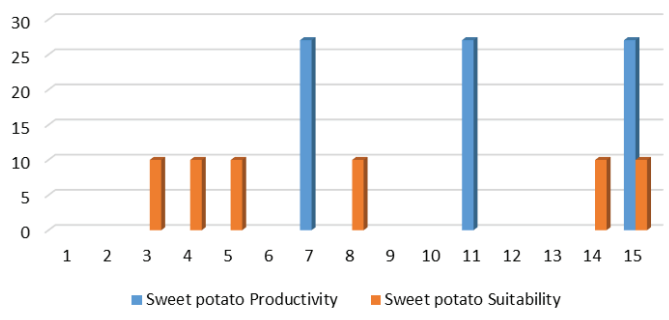

Fig. 4. Comparison between Productivity and Suitability of Sweet Potato Commodities.

Sweet potato farming in Madiun Regency is only spread over three sub-districts that have high productivity. Based on the results of land suitability analysis, there should be six sub-districts suitable for sweet potato commodities. This can happen like a cassava commodity, that sweet potato is also not a staple commodity that is consumed daily today. This causes farmers not to choose sweet potato or cassava commodities, even though the characteristics of the land area suitable for these commodities.

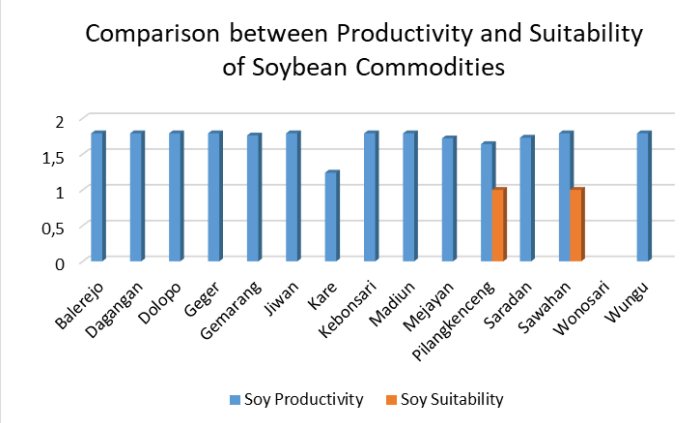

Fig. 5. Comparison between Productivity and Suitability of Soybean Commodities.

Soybean agricultural commodity is a commodity that is often consumed by the community because it contains high protein. Almost all sub-districts in Madiun Regency have soybean productivity except for Wonosari District. According to the results of land suitability, there are only two sub-districts that are most suitable for soybean commodities, namely Pilangkenceng District and Sawahan District. Both subdistricts have the same soybean productivity as other sub-districts, although other areas have less suitable land characteristics for soybeans. In detail, Sawahan Subdistrict is suitable for soybean commodity according to its productivity results, classified as higher than other sub-districts. For Pilangkenceng Sub-district however, despite being in accordance with the the characteristics of the land, it has the second-lowest productivity after Kare District.

Comparison between Productivity and Suitability of Green Bean Commodities

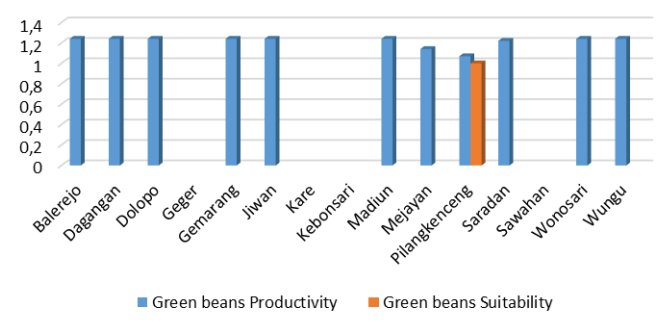

Fig. 6. Comparison between Productivity and Suitability of Green Bean Commodities.

The chart above is a comparison between land suitability for mung bean and its productivity in Madiun Regency. The green bean commodity in Madiun Regency is only in accordance with the characteristics of the land in the Pilangkenceng District. However, based on productivity data, Pilangkenceng District has the lowest green bean productivity in Madiun Regency. The comparison is inversely proportional which can be influenced by many factors such as plant-attacking pests, extreme weather that causes farmers to fail to harvest, etc.

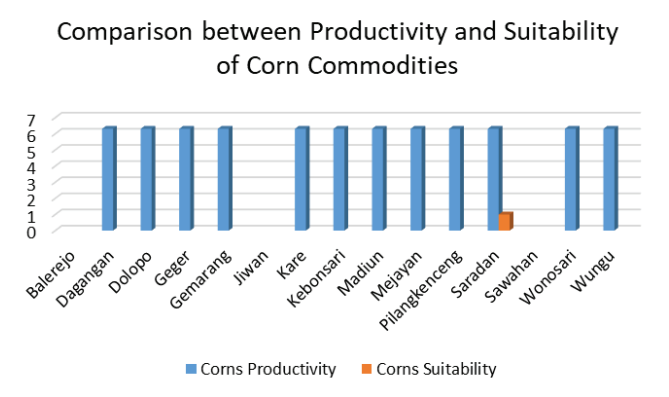

Fig. 7. Comparison between Productivity and Suitability of Corn Commodities.

The last agricultural commodity that matches the characteristics of the land in Madiun Regency is corn. The picture above shows that there is only one area suitable for corn commodities, which is Saradan District. However, it can be seen that corn productivity is primarily produced in almost all sub-districts in Madiun Regency. Although other areas based on land characteristics are not suitable for corn farming, they still have fairly high corn productivity. In addition to having unsuitable land characteristics, this great productivity can be supported by farmers' strategies in cultivating corn, such as by cultivating the land or regulating irrigation to produce high productivity.

\subsection{The Effect of Land Characteristics on Agricultural Productivity}

The relationship between land characteristics and agricultural productivity can occur because of a causal relationship between the two variables. The correlation allows the influence of one variable that affects other variables. The influencing variable in this study is land 
characteristics, and the affected variable is agricultural productivity.

Before multiple linear regressions, the data normality test was conducted so that the data produced valid results. Data normality test was carried out on all data including characteristics data and agricultural productivity data. Normality conducted through SPSS software can be seen in the table below:

Table 3. Normality Test.

\begin{tabular}{l|r|r|r} 
& \multicolumn{3}{|c}{ Shapiro-Wilk } \\
& Statistic & \multicolumn{1}{c}{ df } & \multicolumn{1}{c}{ Sig. } \\
\hline Ln_Temperatur & .859 & 15 & .024 \\
\hline Ln_Kelembaban & .815 & 15 & .006 \\
\hline Ln_Curahhujan & .967 & 15 & .812 \\
\hline Ln_pH & .842 & 15 & .013 \\
\hline Ln_KTK & .961 & 15 & .714 \\
\hline Ln_corganik & .938 & 15 & .353 \\
\hline Ln_N & .943 & 15 & .417 \\
\hline Ln_P & .941 & 15 & .390 \\
\hline Ln_K & .603 & 15 & .000 \\
\hline Ln_Pasir & .970 & 15 & .862 \\
\hline Ln_Debu & .951 & 15 & .533 \\
\hline Ln_Liat & .901 & 15 & .099 \\
\hline Ln_Padi & .901 & 15 & .098 \\
\hline
\end{tabular}

*. This is a lower bound of the true significance.

\section{a. Lilliefors Significance Correction}

The results of the data normality test showed that there were 8 data on land characteristics that became the influencing variable, and one data on agricultural productivity, which is rice productivity, became the affected variable. After getting the data that is normally distributed, multiple linear regressions can be done as shown in the table below:

Table 4. Multiple Linear Regression Test.

\begin{tabular}{|c|c|c|}
\hline \multicolumn{3}{|c|}{ Model Summary ${ }^{\mathbf{b}}$} \\
\hline & Model & 1 \\
\hline & $\mathrm{R}$ & $.932^{\mathrm{a}}$ \\
\hline \multicolumn{2}{|c|}{ R Square } & .868 \\
\hline \multicolumn{2}{|c|}{ Adjusted R Square } & .693 \\
\hline \multicolumn{2}{|c|}{ Std. Error of the Estimate } & .00223 \\
\hline \multirow{5}{*}{ Change Statistics } & R Square Change & .868 \\
\hline & F Change & 4.943 \\
\hline & df1 & 8 \\
\hline & $\mathrm{df} 2$ & 6 \\
\hline & Sig. F Change & .034 \\
\hline
\end{tabular}

a. Predictors: (Constant), Ln_Rainfal, Ln_Sand, Ln_P,

Ln_c-organic, Ln_N, Ln_Dust, Ln_Clay, Ln_CEC

b. Dependent Variable: Ln_Rice Productivity

The Model Summary table above results from multiple linear regression of 8 land characteristics variables and rice agricultural productivity variables.
The relationship between these variables shows an influence of land characteristics variables as indicated by an R-value of $0.932 \mathrm{a}$, which means that $93 \%$ of land characteristics variables affect rice productivity and other factors influence the rest. The significance of land characteristics influence can be identified through the value of Sig. F Change above. A significance value of less than 0.05 indicates that the independent variable has a significant effect, and the results of the analysis above show the value of Sig. F Change is 0.034 which means that the variable of land characteristics significantly affects rice productivity. The effect of the independent variable was tested again using 2 tests to determine the impact simultaneously and partially. Below is a table of the results of the Simultaneous F Test of the variable land characteristics.

Table 5. F-Simultaneous Test.

\begin{tabular}{|c|c|c|c|c|c|}
\hline \multicolumn{6}{|l|}{ ANOVA $^{\mathrm{a}}$} \\
\hline Model & $\begin{array}{l}\text { Sum of } \\
\text { Squares }\end{array}$ & df & $\begin{array}{l}\text { Mean } \\
\text { Square }\end{array}$ & $\mathrm{F}$ & Sig. \\
\hline 1 Regression & .000 & 8 & .000 & 4.943 & $.034^{\mathrm{b}}$ \\
\hline Residual & .000 & 6 & .000 & & \\
\hline Total & .000 & 14 & & & \\
\hline
\end{tabular}

The ANOVA table above is a table of Simultaneous $\mathrm{F}$ test results from 8 land characteristic variables. This test is proven by the calculated $\mathrm{F}$ value and $\mathrm{F}$ table. The calculated $\mathrm{F}$ value can be seen in the table above, which is 4.943 , while the F table value is obtained from the distribution of the r-table value at a significance of $5 \%$ or 0.05 is 3.73 . The condition for the simultaneous $F$ test is that if $\mathrm{F}$ count $>\mathrm{F}$ table. The results of the $\mathrm{F}$ test above show that the calculated $\mathrm{F}$ value is $4.934>\mathrm{F}$ table 3.73 , so it can be seen that the variables of land characteristics have a simultaneous (together) effect on agricultural productivity. In addition, testing the effect of the independent variable partially using the T-test as shown in the table 6.

Variables of land characteristics, totaling 8 variables, may have their respective effects on agricultural productivity or partial (alone) effects. The partial effect can be seen in the t value in table 5. It is the same as the Simultaneous F test, namely by comparing the calculated $\mathrm{T}$ values and $\mathrm{T}$ tables. The calculated $\mathrm{T}$ value can be seen in the table 6 , while the $\mathrm{T}$ table value is sought from the distribution of the $t$ table value with a probability of 0.025 , and in this study, the $\mathrm{T}$ table value is 2.447 . The calculated $\mathrm{T}$ value is greater than the $\mathrm{T}$ table, and then the variable has a partial effect. This test shows that 2 variables have $T$ count more than the $\mathrm{T}$ table, namely the $\mathrm{CEC}$ variable and the sand variable.

Cation exchange capacity (CEC) is one of the characteristics of the land that is important in increasing nutrient sources by binding soil nutrients. The level of $\mathrm{CEC}$ in the soil always affects soil fertility and its impact 
Table 6. Partial-T Test

Coefficients $^{\mathrm{a}}$

\begin{tabular}{|c|c|c|c|c|c|c|c|c|c|c|c|}
\hline \multirow{2}{*}{\multicolumn{2}{|c|}{ Model }} & \multicolumn{2}{|c|}{$\begin{array}{l}\text { Unstandardized } \\
\text { Coefficients }\end{array}$} & \multirow{2}{*}{$\begin{array}{l}\text { Standardized } \\
\text { Coefficients } \\
\text { Beta }\end{array}$} & \multirow[t]{2}{*}{$\mathrm{t}$} & \multirow[t]{2}{*}{ Sig. } & \multicolumn{3}{|c|}{ Correlations } & \multicolumn{2}{|c|}{$\begin{array}{l}\text { Collinearity } \\
\text { Statistics }\end{array}$} \\
\hline & & B & $\begin{array}{l}\text { Std. } \\
\text { Error }\end{array}$ & & & & $\begin{array}{l}\text { Zero- } \\
\text { order }\end{array}$ & Partial & Part & Tolerance & VIF \\
\hline \multirow{9}{*}{1} & (Constant) & 1.846 & .068 & & 27.015 & .000 & & & & & \\
\hline & Ln_CEC & .031 & .006 & 3.089 & 5.286 & .002 & .187 & .907 & .783 & .064 & 15.559 \\
\hline & $\begin{array}{l}\text { Ln_c- } \\
\text { organic }\end{array}$ & -.001 & .003 & -.058 & -.274 & .793 & .111 & -.111 & $\begin{array}{l}- \\
.041\end{array}$ & .494 & 2.024 \\
\hline & Ln_N & -.005 & .004 & -.258 & -1.203 & .274 & .195 & -.441 & $\begin{array}{l}- \\
.178\end{array}$ & .477 & 2.097 \\
\hline & Ln_P & -.002 & .001 & -.233 & -1.244 & .260 & -.292 & -.453 & $\begin{array}{l}- \\
.184\end{array}$ & .624 & 1.604 \\
\hline & Ln_Sans & .013 & .003 & 2.773 & 5.166 & .002 & .093 & .904 & .766 & .076 & 13.118 \\
\hline & Ln_Dust & .001 & .005 & .034 & .127 & .903 & -.191 & .052 & .019 & .298 & 3.357 \\
\hline & Ln_Clay & -.002 & .005 & -.253 & -.514 & .625 & .102 & -.205 & $\begin{array}{l}- \\
.076\end{array}$ & .091 & 10.987 \\
\hline & Ln_Rainfal & -.019 & .008 & -.473 & -2.455 & .049 & -.116 & -.708 & $\begin{array}{l}- \\
.364\end{array}$ & .592 & 1.688 \\
\hline
\end{tabular}

a. Dependent Variable: Ln_Rice Productivity

on crop productivity. This study is in line with research conducted by [9] which found that the increase in soil CEC due to the application of granular solid organic fertilizer with NPK fertilizer caused an increase in rice yields by $54 \%$ without the treatment.

Characteristics of soil texture, especially sand, showed a partial effect on rice productivity. This result is also in line with research [10] which stated that sandy soil texture influences rice production. The positive impact of sandy soil is that the rice harvest index is significantly higher than clay soil where pest disease attacks on clay soil is higher.

\section{Conclusion}

There are 6 referred commodities in Madiun Regency based on land suitability analysis, namely rice, corn, soybeans, peanuts, sweet potatoes, and cassava. Rice commodity is suitable for 7 sub-districts, namely Balerejo, Jiwan, Madiun, Mejayan, Pilangkenceng, Wonosari and Wungu sub-districts. Sweet potato commodity is suitable for 6 sub-districts, namely Dolopo, Geger, Gemarang, Kebonsari, Wonosari, and Wungu sub-districts. Cassava commodity is suitable in 8 sub-districts, namely Dagangan, Dolopo, Geger, Gemarang, Kare, Kebonsari, Wonosari, and Wungu sub-districts.Soybean commodity is only suitable in 2 sub-districts, namely Pilangkenceng and Sawahan Districts. Corn commodity is only suitable for 1 subdistrict, which is in Saradan District. The green bean commodity is only suitable in 1 sub-district, namely Pilangkenceng District which is in Saradan District. The green bean commodity is only suitable in 1 sub-district, namely Pilangkenceng District.

Land characteristics significantly affect rice productivity by $93 \%$. The influence of 8 variables of land characteristics simultaneously affects agricultural productivity. Still, there are only 2 variables of land characteristics that have partial impact, namely the characteristics of CEC and sand characteristic.

\section{References}

1. S. Hadi, 1 (2011)

2. R. D. S. Kuncoro, Pros. Semin. Nas. Geogr. UMS 8, 370 (2017)

3. S. W. Tjokrokusumo, J. Teknol. Lingkung. 3, $136(2002)$

4. M. Muhammad and U. Wasit, Semin. Nas. Dalam Rangka Dies Natalis UNS Ke 43 Tahun 2019 3, 42 (2019)

5. Badan Pus. Stat. (2019)

6. M. A. Oktaviani and H. B. Notobroto, J. Biometrika Dan Kependud. 3, 127 (2014)

7. D. N. A. Janie, Statistik Deskriptif Dan Regresi Linier Berganda Dengan SPSS (Semarang University Publisher, 2012)

8. S. L. Wibowo, Analisis Efesiensi Alokatif Faktor-Faktor Produksi Dan Pendapatan Usahatani Padi (Oryza Sativa L.) (Studi Kasus Di Desa Sambirejo, Kecamatan Saraden, Kabupaten Madiun (Fakultas Pertanian, Universitas Brawijaya, 2012)

9. $\quad$ E. S. Puspita, 2013 (2013)

10. L. Hadiawati and A. Suriadi, 311 (2013) 